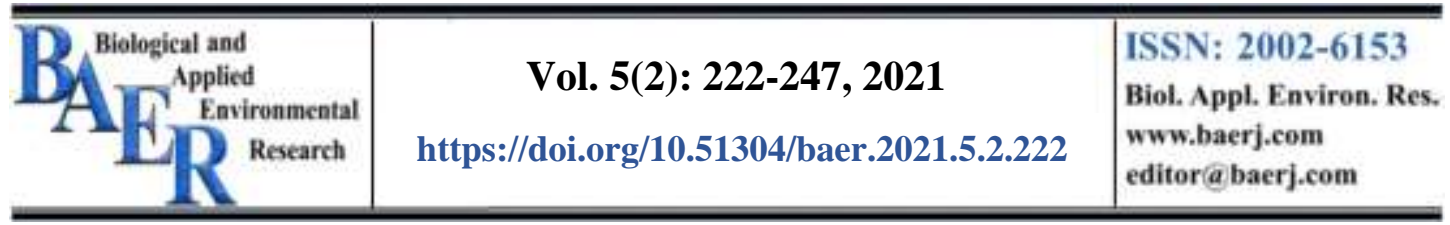

\title{
Tolerance of Benthic Diatoms to Severe Environmental Stress: A Case Study in Shatt Al-Arab River, Basrah, Iraq
}

\author{
Rehab N. Al-Saedy* \& Maitham A. Al-Shaheen \\ Department of Ecology, College of Science, University of Basrah, Basrah, Iraq \\ *Corresponding author: rehabalsaedy@gmail.com
}

\begin{abstract}
The present work aims at investigating the ability of diatoms to reestablish their community after a severe environmental stress such desiccation. Diatoms were subjected to extreme environmental stress to observe their survival capability. Samples of sediment were collected from three sites, Maqal, Abu Flos and Al-Faw along the course of Shatt Al-Arab river. Different temperature regimes were implemented for testing the ability of diatoms to recover desiccation. Experiments were performed at various temperatures, 10, $15,20,25,30,35$ and $40{ }^{\circ} \mathrm{C}$. A total of 67 diatom species were identified and included freshwater forms (25\%), brackish water forms $(25 \%)$ and marine species (26\%), as well as $24 \%$ of taxa with undefined ecological preferences. The recovery rate of diatom species at all sites appeared to be rather similar. $40 \%, 38 \%$ and $37 \%$ of all taxa encountered were able to recover desiccation at sites 1, 2 and 3, respectively. Recovering ability of those species varies with variable temperature. Favourable temperature for most species to regrow ranged between 15 and $25{ }^{\circ} \mathrm{C}$. Nitzschia palea exhibited the maximum growth rate at all temperatures $\left(10-35{ }^{\circ} \mathrm{C}\right) .32 \%$ of all epiphytic species encountered were able to recover at $20{ }^{\circ} \mathrm{C}$. Five species: Craspedostauros britannicus, Nitzschia invisitata, Pinnularia quadratarea, Simonsenia sp. and Tryblionella plana were not previously reported in Iraq and considered as new to the region. A new species, Synedropsis abuflosensis, was found. The outcome of the present work clearly indicates that some species of diatoms can recover after exposure to sever environmental stress.
\end{abstract}

Keywords: Diatoms, Desiccation, Environmental stress, Shatt Al-Arab river, Temperature

\section{Introduction}

Diatoms are the dominant phytoplankton group that occur in all aquatic habitats; freshwater, brackish water, marine and some live on exposed wet soils (terrestrial) (Quiroga \& Chretiennot-Dinet, 2004; Warkiewicz et al., 2018). They are very important components of the aquatic environment as they form "with other algae" the base of the trophic levels. Diatoms constitute a fundamental link between primary (autotrophic) and secondary (heterotrophic) production. Many microorganisms feed on diatoms and in this way, they are integrated into aquatic food webs (Mann et al., 2017). They are responsible for $20 \%$ to $25 \%$ of global 
carbon fixation and $40 \%$ of primary production in all oceans and constitute the major source of atmospheric oxygen (Berger, 2007; Renaudie, 2016).

Diatoms are widely distributed from equator to poles, and inhabit various types of substrates (Round et al., 1990). They live either freely in the water column (planktonic diatoms) or spend most of their time living on the bottom (benthic diatoms). According to their living mode, benthic diatoms can be divided into two subgroups: motile benthic diatoms and attached benthic diatoms (Pinckney et al., 1994; Dickman et al., 2005).

Diatoms are usually more sensitive to environmental changes than other benthic microalgae (Schneider et al., 2012). Thus, they are commonly used throughout the world as bioindicators to monitor changes in water quality due to their specific tolerance to various environmental parameters: nutrient concentrations, $\mathrm{pH}$, salinity, temperature, conductivity and organic pollution (Gale, 2016). One of the most influencing environmental parameters on diatom distribution, occurrence and growth is temperature, which is responsible for the appearance or disappearance of the different diatom species (Bopp et al., 2005).

Diatoms exist and thrive across many environments ranging from cold water to hot springs (Maguire et al., 2013). Some diatoms have a rather narrow temperature range outside which cells die (Anderson, 2000; Zhang et al., 2018). On the other hand, temperature affects diatoms more than any other environmental factor and this effect can be in one of two distinct ways: directly on metabolic rates and indirectly by its impact on nutrient availability and uptake (Lewandowska et al., 2014). Temperature plays significant role in diatoms primary production (Berges et al., 2002; Behrenfeld et al., 2006). Generally, productivity increase in lower temperature as a result of increasing activity of some enzymes associated with photosynthesis (Prelle et al., 2019).

In Southern Iraq, particularly in Basrah District, environmental conditions are becoming severe during the prolonged warm periods which lead to desiccation in several aquatic habitats such as the shallow ponds, marginal marshes and coastal areas of Shatt Al-Arab river. Even so, no attempt was made to study the ability of benthic microalgae to survive such conditions. The only few investigations made on the tolerance of diatoms to environmental conditions focused on the effect of various environmental parameters such as temperature on planktonic diatoms (Hussein et al., 2009; Al-Shawi et al., 2012). These authors studied the effect of thermal water discharged from electric power plants in Najebiya and Hartha sites on planktonic algae and merely provided list of species found in the area. On a very narrow scale, Al-Hassani et al. (2009) studied the optimum temperature and light intensity for the growth of Nitzschia palea in culture conditions.

The present study aims at investigating the ability of diatoms to recover after prolonged periods of high temperature and desiccation. It is the first study in the region to elaborate the survival rate of diatoms in harsh environmental conditions. 


\section{Material and Methods}

\section{Study Area}

Shatt Al-Arab River $\left(30^{\circ} 18^{\prime} \mathrm{N}, 48^{\circ} 53^{\prime} \mathrm{E}\right)$ flows through Basrah City in Southern Iraq and extends for approximately $204 \mathrm{~km}$ (Fig. 1). It originates by the confluence of the two major rivers in Iraq, Tigris and Euphrates, at Qurna City north of Basrah, flowing southwards to discharge into the Arabian Gulf. The river width ranges between $400 \mathrm{~m}$ around Basrah City to $1500 \mathrm{~m}$ further south at Faw Town, with a depth ranging from 7 to $14 \mathrm{~m}$, depending on tidal cycle (Abdullah, 1990; Mohamed \& Abood, 2017).

Ecological characters of the Shatt Al-Arab River are affected by the semi-diurnal tidal cycle of the Arabian Gulf. During high tide, water rises to ca $3 \mathrm{~m}$ at Faw City and ca $0.5 \mathrm{~m}$ around Basrah urban region (Al-Hassan \& Hussain, 1985). Historically, Shatt Al-Arab River also receives water from two tributaries, Swaib and Karun rivers which flow in the Iranian territories. Swaib River receives water from Huwaiza Marsh and discharges into water impoundments to the southern parts of Qurna City. Karun River discharges into the southern part of Shatt Al-Arab river. Both tributaries, however, were diverted into the Iranian land and no longer supply water to Shatt Al-Arab River (Al-Hassan \& Hussain, 1985).

Shatt Al-Arab River is the main waterway in Basrah and it is largely used for drinking, agriculture and transport. Parts of the river, close to crowded populations, suffers from high level of pollution, both organic and inorganic. In many places, untreated domestic and industrial outflows find their way to the river, causing various environmental stresses, which affect both human and aquatic life (Naff \& Hanna, 2003; Mohamed \& Abood, 2017).

\section{Sampling and Preparations}

Sampling was carried out During July and August 2020 at three sites along the shoreline of Shatt Al-Arab River (Fig. 1). Site 1 is located at Maqal area $\left(30^{\circ} 34^{\prime}\right.$ $39^{\prime \prime} \mathrm{N}, 47^{\circ} 46^{\prime} 45^{\prime \prime} \mathrm{E}$ ), about $8.1 \mathrm{~km}$ to north of Basrah City center, opposite to AlMaqal port. Site 2 was at Abu Flos village ( $\left.30^{\circ} 27^{\prime} 08^{\prime \prime} \mathrm{N}, 48^{\circ} 01^{\prime} 59^{\prime \prime} \mathrm{E}\right)$, located opposite to Abu Flos port, $25 \mathrm{~km}$ south of Basrah City Center and $45 \mathrm{~km}$ to site 1. Site 3 was selected at Al-Faw City $\left(29^{\circ} 58^{\prime} 22^{\prime \prime} \mathrm{N}, 48^{\circ} 28^{\prime} 14^{\prime \prime}\right.$ E) to represent highly brackish water habitat. 


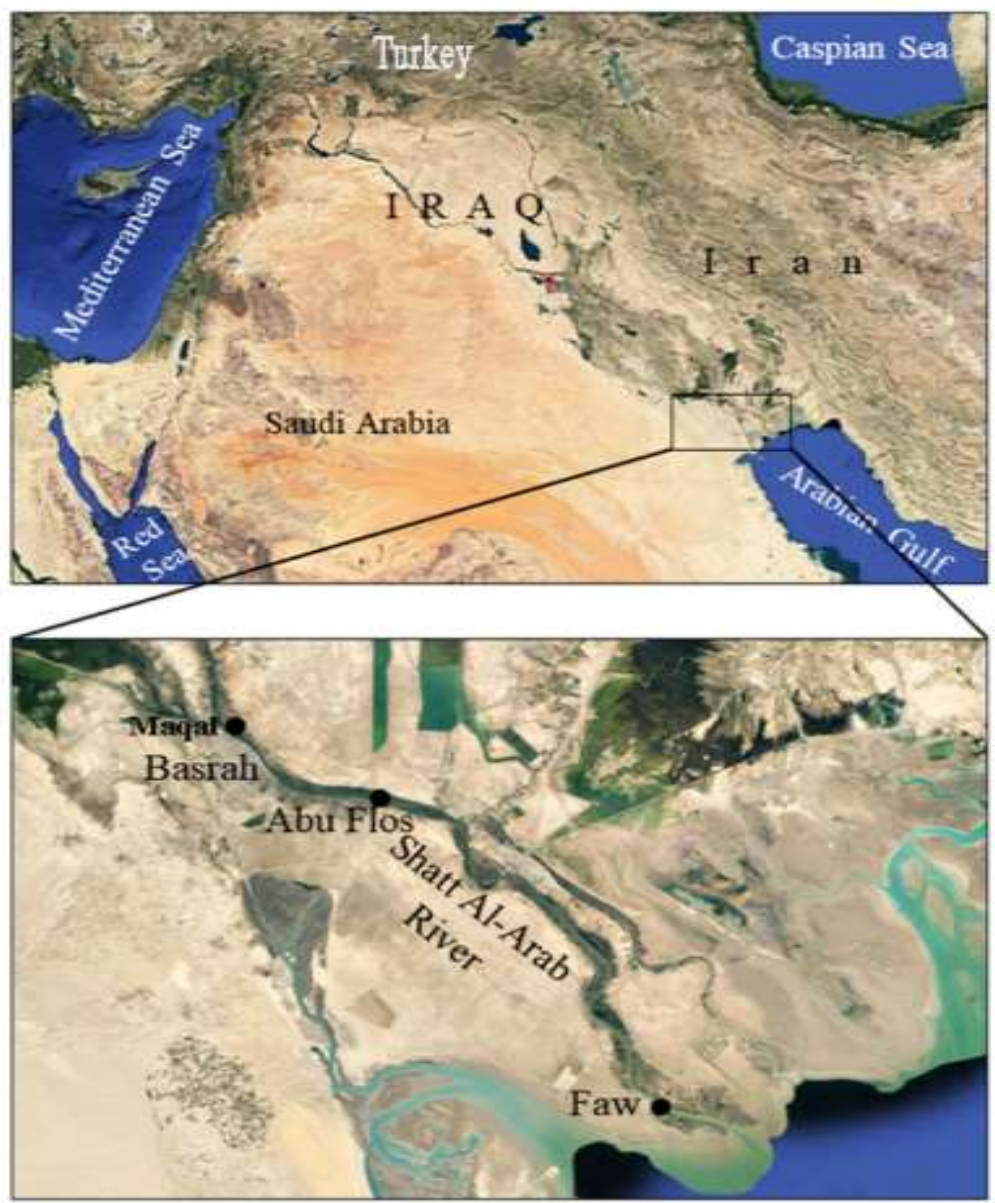

Figure 1: Map showing study area and location of sampling sites (black circles).

\section{Diatoms Collection}

Epipelic diatoms were collected by scrapping the uppermost $0.5 \mathrm{~cm}$ of sediment from randomly selected spots at each site, following the technique described by Eaton \& Moss (1966). All samples were mixed and kept in large containers. Upon return to the laboratory, sediment samples were remixed carefully and transferred into plastic Petri dishes $(9 \mathrm{~cm}$ diameter) with $1 \mathrm{~cm}$ depth. Except for the cover, all Petri dishes were wrapped with aluminum foil to prevent light from penetrating to the sediment and forcing diatom cells to migrate upwards. For each site, 100 Petri dishes were used for various analysis. Small portions of the sediment were directly treated for identification of natural diatom flora (see below).

\section{Water Samples}

From each site, water samples were collected in $10 \mathrm{~L}$ plastic containers for culture experiments. In the laboratory, the water was filtered through GF/C filter to eliminate any organic or suspended material and then left at room temperature. 


\section{Environmental Parameters}

In situ air and water temperature were measured by using ordinary mercury thermometer. Salinity was measured by using portable conductivity meter model Cond 3110 set 1 (WTW- Germany) and a portable pH meter model pH 3110 set 2 (WTW- Germany) was used to measure the hydrogen ion concentration.

\section{Experimental Design}

For testing the ability of diatoms to recover desiccation under different temperature regimes, Petri dishes from all sites (50 Petri dish for each site) were allowed to completely dry at $48-50{ }^{\circ} \mathrm{C}$ ambient temperature, away from dust, and kept for four weeks. Prior to the experiment, four Petri dishes and one liter of filtered natural water from each site were left in the incubator at a particular temperature for 24 hours. This is necessary that dry samples and water have the same temperature specified for the experiment. In the next day, dry samples were covered with the filtered natural water and allowed to acclimatize for 24 hours in the incubator. In order to collect only benthic diatoms that have recovered, a microscope slide or lens tissue were placed on the sediment in each Petri dish. Slides were inspected for growing diatoms every 72 hours for 14 days for each experiment.

For inspecting the preferred temperature for diatoms to recover, experiments were performed at $10,15,20,25,30,35$ and $40^{\circ} \mathrm{C}$. This range of temperature values was selected to mimic the expected temperature fluctuations in the study area during different periods of the year. The effect of each temperature treatment was tested by incubating four replicates of dry sediment for each site in an incubator equipped with cool-white fluorescent tubes at a 16:8-h light: dark cycles. Filtered natural water was added to Petri dishes when necessary to keep sediment samples wet during the course of the experiments. No culture media or other nourishments were incorporated in order to only simulate natural nutrient resources. Growth of diatoms was monitored every 72 hours. This was carried out by removing the slides from the sediment and growing diatoms were completely scrapped in small vials.

Scrapped samples were fixed with $70 \%$ ethanol until the time of further treatment. Diatoms in the vials were later cleaned and permanent slides were made for species identification and relative abundance estimation. Inspection of diatoms recovery was made for five times (every 72 hours) during every temperature experiment which lasted for two weeks. The period of two weeks was initially determined after a poilet experiment for growing dry diatoms which showed that no new growth was appeared after a two weeks incubation period.

\section{Diatom Cleaning and Examination}

Diatom frustules were cleaned by boiling in 30\% concentration hydrogen peroxide following the procedure described in Taylor et al. (2007) and Al-Handal $\&$ Wulff (2008). Cleaned diatom suspension was placed on a coverslip and left to dry at room temperature then mounted in Naphrax ${ }^{\circledR}$ (Brunel microscope Ltd., 
Chippenham, UK). Diatoms were examined and photographed by using Zeiss Axiophot 2 imaging microscope (Carl Zeiss AB), at the Department of Marine Biology, Marine Science Centre, University of Basrah. GBIF (2021) was followed for checking the scientific names and authorities (excluding the year of authority) of all concerned diatom species.

\section{Relative Abundance (RA)}

Relative abundance of all species encountered in both natural and cultivated samples was estimated by counting 400 valves in each slide. Counting was made in transapical lines across the cover slip until 400 counts were reached. RA was estimated according to the following formula:

$\mathrm{RA}=(\mathrm{n} / \mathrm{N}) \times 100$

Where $n=$ number of valves of each species counted and $N=$ total number of valves of all species (400).

\section{Results}

\section{Environmental Parameters}

The environmental features of the three sites are shown in Table 1. Air temperature reached its highest value $\left(42^{\circ} \mathrm{C}\right)$ in July and its lowest value $\left(38^{\circ} \mathrm{C}\right)$ in August. The highest water temperature of $33{ }^{\circ} \mathrm{C}$ was recorded at site 2 , while the lowest temperature reading of $31^{\circ} \mathrm{C}$ was recorded at site 1 . Narrow fluctuation of $\mathrm{pH}$ was observed during the sampling, the maximum value of 8 was at site 3 and the minimum value of 7.2 was at site 1 . The lowest value of salinity (1.5 psu) was recorded at site 1 , while the highest value (5.2 psu) was recorded at site 3 .

Table 1: Environmental parameters at the study sites in Shatt Al-Arab River during July and August 2020.

\begin{tabular}{|l|c|c|c|}
\hline \multirow{2}{*}{\multicolumn{1}{|c|}{ Parameters }} & \multicolumn{3}{|c|}{ Sites } \\
\cline { 2 - 4 } & Site 1 & Site 2 & Site 3 \\
\hline Air temperature $\left({ }^{\circ} \mathrm{C}\right)$ & 38 & 42 & 38 \\
\hline Water temperature $\left({ }^{\circ} \mathrm{C}\right)$ & 31 & 33 & 32 \\
\hline $\mathrm{pH}$ & 7.2 & 7.8 & 8 \\
\hline Salinity $(\mathrm{psu})$ & 1.5 & 3.2 & 5.2 \\
\hline
\end{tabular}

\section{Diatom Species Composition}

In total, 67 diatom species were identified at all sites. These taxa are listed alphabetically in Table 2. Epipelic diatom species assemblages included freshwater forms $(25 \%)$, brackish water forms $(25 \%)$ and marine species $(26 \%)$, the remainder (24\%) were of variable undefined ecological preferences from marine to fresh. In general, most of the encountered species (93\%) were pennate, constituting 64 species belonging to 28 genera. Centric diatoms constituted merely $7 \%$ of the diatom community and included five species belonging to three genera. Nitzschia was the most common genus with 15 species distributed at all sites, followed by Tryblionella with six species, Navicula with four species, Cyclotella with three 
species and Gyrosigma with three species. Other genera were less diverse and were represented by a single species (Table 2). Higher number of species was in August at site 3, while lower number was in July at site 2. five species (Craspedostauros britannicus, Nitzschia invisitata, Pinnularia quadratarea, Simonsenia sp. and Tryblionella plana) found in this study were not previously reported from Iraq and considered as new to the region. Among them, Synedropsis abuflosensis is new to science and its type material has been deposited in the Botanscher Garten und Botanischer Museum, Berlin, under reference no. B 40 0045147. Description and distinguishing features of this species will be dealt with in detail in a separate article.

Table 2: Ecology and relative abundance (RA\%) of the natural diatoms assemblage at the study sites. f: freshwater, b: brackish water, m: marine, un: unknown. Numbers under each site represent RA\%.

\begin{tabular}{|c|c|c|c|c|c|}
\hline Species & Figure & Site 1 & Site 2 & Site 3 & Habitat \\
\hline $\begin{array}{l}\text { Achnanthes brevipes var. intermedia } \\
\text { (Kützing) Cleve }\end{array}$ & Pl. 2: $4 \& 5$ & 1 & - & - & $\mathrm{m}, \mathrm{b}$ \\
\hline $\begin{array}{l}\text { Amphora copulata (Kützing) Schoeman \& } \\
\text { Archibald }\end{array}$ & Pl. 5: 10 & 3 & 1 & - & $\mathrm{f}$ \\
\hline Bacillaria paxillifera (O.F.Müller) Hendey & Pl. 5: 4 & 2.75 & - & - & $\mathrm{b}, \mathrm{m}$ \\
\hline $\begin{array}{lll}\text { Berkeleya scopulorum } & \text { (Brébisson } & \text { ex } \\
\text { Kützing) Cox } & & \end{array}$ & Pl. 2: 14 & - & - & 0.75 & $\mathrm{~m}$ \\
\hline Brachysira sp. & Pl. 3: 7 & - & - & 0.25 & un \\
\hline Caloneis permagna (Bailey) Cleve & Pl. 2: 8 & 1 & - & - & $\mathrm{b}$ \\
\hline Campylodiscus bicostatus Grunow & Pl. 6: 12 & - & - & 0.25 & $\mathrm{~b}$ \\
\hline Cocconeis euglypta Ehrenberg & Pl. 2: 9 & 1 & 0.75 & - & $f, b$ \\
\hline Cocconeis pediculus Ehrenberg & Pl. 2: 11 & 3.5 & - & - & $f, b$ \\
\hline Craspedostauros britannicus Cox & Pl. 5: 6 & - & - & 2 & $\mathrm{~m}$ \\
\hline $\begin{array}{l}\text { Ctenophora pulchella (Ralfs ex Kützing) } \\
\text { Williams \& Round }\end{array}$ & Pl. 1: 11 & - & - & 0.25 & $\mathrm{~b}$ \\
\hline Cyclotella meneghiniana Kützing & Pl. $1: 2 \& 3$ & 3 & 2.5 & 5.25 & $\mathrm{~m}, \mathrm{f}$ \\
\hline Cyclotella striata (Kützing) Grunow & Pl. 1: 1 & 2.25 & 6.25 & 10 & $f, b$ \\
\hline Cyclotella sp. & Pl. 1: 4 & - & 2.75 & 5.5 & un \\
\hline Diatoma vulgaris Bory & Pl. 1: $7 \& 8$ & 1.5 & _ & 0.25 & $f, b$ \\
\hline $\begin{array}{l}\text { Entomoneis corrugata (Giffen) Witkowski, } \\
\text { Lange-Bertalot \& Metzeltin }\end{array}$ & Pl. 6: $10 \& 11$ & 7.5 & 6.25 & 3.75 & $\mathrm{~b}$ \\
\hline $\begin{array}{l}\text { Fallacia pygmaea (Kützing) Stickle \& } \\
\text { D.G.Mann }\end{array}$ & Pl. 5: 9 & - & - & 0.75 & $\mathrm{~b}, \mathrm{f}$ \\
\hline $\begin{array}{l}\text { Fragilaria koensabbei Al-Handal \& Al- } \\
\text { Shaheen }\end{array}$ & Pl. 1: 13 & - & 0.25 & 0.25 & $\mathrm{f}$ \\
\hline $\begin{array}{l}\text { Giffenia cocconeiformis (Grunow) Round } \\
\& \text { Basson }\end{array}$ & Pl. 5: 7 & - & - & 0.5 & $\mathrm{~m}, \mathrm{~b}$ \\
\hline Gomphonella olivacea Rabenhorst & Pl. 2: 6 & 2.25 & - & - & $\mathrm{m}$ \\
\hline Gomphonema affine Kützing & Pl. 2: 3 & 0.75 & - & - & $\mathrm{f}$ \\
\hline $\begin{array}{l}\text { Gyrosigma acuminatum } \\
\text { Rabenhorst }\end{array}$ & Pl. 3: 11 & 0.5 & - & - & $\mathrm{f}, \mathrm{b}$ \\
\hline Gyrosigma wormleyi (Sullivant) Boyer & Pl. 3: 8 & 0.75 & - & - & $\mathrm{f}$ \\
\hline Gyrosigma sp. & Pl. 3: 9 & 1.5 & - & 0.5 & un \\
\hline
\end{tabular}




\begin{tabular}{|c|c|c|c|c|c|}
\hline Halamphora sp. 1 & Pl. 5: 11 & 4 & - & 4.5 & un \\
\hline Halamphora sp. 2 & Pl. 5: 12 & - & - & 3.75 & un \\
\hline Lindavia sp. & Pl. 5: 6 & 2.75 & 2.5 & - & un \\
\hline Mastogloia smithii Thwaites ex W. Smith & Pl. 2: 2 & - & 0.5 & - & $\mathrm{b}$ \\
\hline Navicula erifuga Lange-Bertalot & Pl. 3: $1 \& 2$ & 6.5 & 3 & 0.75 & $\mathrm{~b}$ \\
\hline $\begin{array}{l}\text { Navicula viridula var. Rostellata (Kützing) } \\
\text { Cleve }\end{array}$ & Pl. 3: 3 & 4.75 & - & - & $\mathrm{f}$ \\
\hline Navicula sp. 1 & Pl. 3: 4 & 0.75 & - & - & un \\
\hline Navicula sp. 2 & Pl. 3: 5 & - & 4.75 & - & un \\
\hline Nitzschia brevissima Grunow & Pl. 4: 14 & 4.75 & 6.75 & - & $\mathrm{b}$ \\
\hline Nitzschia clausii Hantzsch & Pl. 5: 3 & 6.5 & 8.75 & 7.25 & $\mathrm{~b}, \mathrm{f}$ \\
\hline Nitzschia elegantula Grunow & Pl. 4: 10 & 2.75 & 5 & 0.25 & $\mathrm{f}$ \\
\hline Nitzschia filiformis (W.Smith) Hustedt & Pl. 4: 13 & 3.5 & 3 & - & $\mathrm{b}$ \\
\hline Nitzschia gracilis Hantzsch & Pl. 4: 11 & 0.75 & 5.25 & 1.25 & $\mathrm{f}$ \\
\hline Nitzschia hybrida Grunow & Pl. 4: 2 & - & - & 1.75 & $\mathrm{~b}$ \\
\hline Nitzschia invisitata Hustedt & Pl. 5: 8 & 3.25 & - & - & $\mathrm{f}$ \\
\hline Nitzschia lorenziana Grunow & Pl. 4: 7 & - & - & 4 & $\mathrm{~b}$ \\
\hline Nitzschia obtusa W.Smith & Pl. 5: $1 \& 2$ & 5.25 & 6.75 & - & $\mathrm{m}, \mathrm{b}$ \\
\hline Nitzschia palea (Kützing) W.Smith & Pl. 4: $8 \& 9$ & 6 & 8.25 & 9.5 & $\mathrm{f}$ \\
\hline Nitzschia scalpelliformis Grunow & Pl. 4: 6 & - & 6.25 & 2.75 & $\mathrm{~b}$ \\
\hline Nitzschia sigma W.Smith & Pl. 4: 1 & 3.5 & - & 5 & $\mathrm{~m}, \mathrm{~b}, \mathrm{f}$ \\
\hline $\begin{array}{l}\text { Nitzschua umbonata (Ehrenberg) Lange- } \\
\text { Bertalot }\end{array}$ & Pl. 4: 12 & 3.75 & - & 3.75 & $\mathrm{~m}, \mathrm{f}$ \\
\hline Nitzschia sp. 1 & Pl. 4: 4 & - & - & 0.75 & un \\
\hline Nitzschia sp. 2 & Pl. 4: 5 & - & - & 0.75 & un \\
\hline $\begin{array}{lll}\text { Petrodictyon } & \text { gemma } & \text { (Ehrenberg) } \\
\text { D.G.Mann } & & \\
\end{array}$ & Pl. 6: 9 & - & - & 7.5 & $\mathrm{~m}$ \\
\hline $\begin{array}{l}\begin{array}{l}\text { Pinnularia quadratarea (A. Schmidt) } \\
\text { Cleve }\end{array} \\
\end{array}$ & Pl. 5: 5 & - & - & 0.75 & $\mathrm{~m}$ \\
\hline Placoneis clementis (Grunow) Cox & Pl. 2: 12 & - & - & 2 & $\mathrm{f}$ \\
\hline $\begin{array}{l}\text { Planothidium delicatulum (Kützing) } \\
\text { Round \& Bukhtiyarova }\end{array}$ & Pl. 2: 7 & 0.5 & - & - & $f, b$ \\
\hline $\begin{array}{lll}\text { Pleurosigma angulatum } & \text { (Queckett) } \\
\text { W.Smith } & \\
\end{array}$ & Pl. 3: 10 & - & - & 0.25 & $\mathrm{~m}$ \\
\hline $\begin{array}{l}\text { Prestauroneis crucicula (W.Smith) Genkal } \\
\text { \& Yarushina }\end{array}$ & Pl. 2: 10, 13 & 1.75 & 1 & - & $\mathrm{m}, \mathrm{f}$ \\
\hline $\begin{array}{l}\text { Rhoicosphenia abbriviata } \quad \text { (C.Agardh) } \\
\text { Lange-Bertalot }\end{array}$ & Pl. 2: 1 & - & 0.5 & - & $\mathrm{f}$ \\
\hline $\begin{array}{llll}\text { Scoliopleura } & \text { basrensis } & \text { Al-Handal } & \& \\
\text { Pennesi } & & \\
\end{array}$ & Pl. 3: 6 & 0.25 & - & - & $\mathrm{b}$ \\
\hline Simonsenia sp. & Pl. 1: 9 & - & - & 2.75 & un \\
\hline Surirella striatula Turpin & Pl. 6: 8 & - & - & 0.5 & un \\
\hline Surirella sp. 1 & Pl. 6: 7 & - & - & 0.25 & un \\
\hline $\begin{array}{l}\text { Synedropsis abuflosensis Al-Handal, Al- } \\
\text { Shaheen \& Al-Saedy }\end{array}$ & Pl. 1: 12 & - & 4 & - & un \\
\hline Thalassiosira sp. & Pl. 1: 5 & - & - & 0.5 & un \\
\hline $\begin{array}{lll}\text { Tryblionella } & \text { coarctata } & \text { (Grunow) } \\
\text { D.G.Mann } & & \\
\end{array}$ & Pl. 6: 4 & 4 & - & - & $\mathrm{m}$ \\
\hline $\begin{array}{lll}\text { Tryblionella } & \text { granulata } & \text { (Grunow) } \\
\text { D.G.Mann } & & \end{array}$ & Pl. 6: 6 & - & 3.75 & 1.75 & $\mathrm{~m}$ \\
\hline
\end{tabular}




\begin{tabular}{|l|c|c|c|c|c|}
\hline $\begin{array}{l}\text { Tryblionella hungarica (Grunow) } \\
\text { Frenguelli }\end{array}$ & Pl. 6: 3 & 2.25 & - & 0.25 & $\mathrm{~b}$ \\
\hline Tryblionella littoralis (Grunow) D.G.Mann & Pl. 6: 1 & - & 5.75 & - & $\mathrm{m}$ \\
\hline Tryblionella plana (W.Smith) Pelletan & Pl. 6: 2 & - & 4.25 & - & $\mathrm{m}$ \\
\hline Tryblionella sp. 1 & Pl. 6: 5 & - & - & 4.25 & $\mathrm{un}$ \\
\hline $\begin{array}{l}\text { Williamsella iraqiensis Al-Handal \& } \\
\text { Kociolek }\end{array}$ & Pl. 1:10 & - & 0.25 & 0.25 & $\mathrm{~b}$ \\
\hline
\end{tabular}

\section{Effect of Temperature on Diatom Species Recovery}

The recovery rate of diatom species at all sites appeared to be rather similar. A total of 40, 38 and $37 \%$ of all taxa encountered at all three sites respectively were able to recover from desiccation. Recovering ability of those species varies with variable temperature. Suitable temperature for most species ranged between 15 and $25{ }^{\circ} \mathrm{C}$, although few species flourished at higher temperatures. No growth was observed at $40{ }^{\circ} \mathrm{C}$. Figures 2, 3 and 4 illustrate the time and abundance (RA\%) of taxa recovered at all sites. To better describe the ability of species to recover, each species is treated separately in the following and taxa are arranged depending on their recovery time and abundance after submerging dry material in water.

Nitzschia palea (Pl. 4, Figs. 8 \& 9): This is the only species that recovered at all sites. Its regrowth started after three days and constituted the highest growth rate with a relative abundance of $78 \%$ at site 3 where it dominated diatom assemblage. The species was able to recover at all temperature treatments with high growth frequency.

Nitzschia filiformis (Pl. 4, Figs. 3 \& 13): This species was found only at sites 1 and 2. It recovered after three days with a high growth rate, constituting $62.2 \%$ of the total recovered diatom species at site 1 for $10^{\circ} \mathrm{C}$ and $39.9 \%$ for $30^{\circ} \mathrm{C}$ at site 1 .

Tryblionella sp. 1 (Pl. 6, Fig. 5): This species was observed only at site 3. Its regrowth began after three days with a growth rate constituting $49.28 \%$ of the recovered diatom species at this site for $10^{\circ} \mathrm{C}$.

Synedropsis abuflosensis (Pl. 1, Fig. 12): This is a new species, recorded only at site 2 . It took three days to recover with high growth rate, constituting $41 \%$ of the total recovered diatom taxa at $10{ }^{\circ} \mathrm{C}$, and $35.5 \%$ at $25^{\circ} \mathrm{C}$.

Nitzschua umbonata (Pl. 4, Fig. 12): This species appeared at sites 1 and 3. It returned after three days only at site 1 with a high growth rate accounting for $35.4 \%$ of the recovered diatom species at $25^{\circ} \mathrm{C}$ and $25.9 \%$ at $30{ }^{\circ} \mathrm{C}$.

Fragilaria koensabbei (Pl. 1, Fig. 13): This species was observed at sites 2 and 3. It was able to grow after three days of incubation. The best growth rate at site 2 with a relative abundance of $26.3 \%$ at $10{ }^{\circ} \mathrm{C}$ and $24 \%$ at $30{ }^{\circ} \mathrm{C}$.

Nitzschia gracilis (Pl. 4, Fig. 11): This species was found at all sites. Its regrowth began after three days only at sites 1 and 2. It reached its largest growth rate at site 1 , accounting for $26 \%$ and $20.3 \%$ of the recovered diatoms at 15 and 20 ${ }^{\circ} \mathrm{C}$, respectively.

Entomoneis corrugata (Pl. 6, Figs.10 \& 11): This species started to appear after three days at all sites with an ability to regrow at wider temperature range (15-30 
${ }^{\circ} \mathrm{C}$ ), with the maximum relative abundance of $25.8 \%$ at $20{ }^{\circ} \mathrm{C}$ in site 3 and $15.8 \%$ at $20{ }^{\circ} \mathrm{C}$ in site 2 .

Cyclotella striata (Pl. 1, Fig. 1): This species appeared at all sites. Its regrowth started after three days at sites 2 and 3 . The highest growth rate was observed at site 3 with a relative abundance of $25.1 \%$ at $10{ }^{\circ} \mathrm{C}$. C. striata exhibited ability to regrow and survive at $35{ }^{\circ} \mathrm{C}$ with a growth rate of $22 \%$. C. striata and $N$. palea were the only species that could grow at $35^{\circ} \mathrm{C}$.

Nitzschia sp. 1 (Pl. 4, Fig. 4): This species was found at site 3. It began to regrow after six days, with a growth rate of $19.8 \%$ of the total recovered diatom species at $30^{\circ} \mathrm{C}$.

Williamsella iraqiensis (Pl. 1, Fig. 10): This species was observed at sites 2 and 3 . It began to regrow after three days at both sites, with the highest growth rates of $17.5 \%$ and at $9.5 \%$ at 20 and $15{ }^{\circ} \mathrm{C}$, respectively at site 2 .

Cyclotella menighiniana (Pl. 1, Figs. $2 \& 3$ ): This species was found at all sites. It took three days to regrow at sites 2 and 3, with the highest growth rate of $10.63 \%$ at $10^{\circ} \mathrm{C}$ at site 3 .

Nitzschia elegantula (Pl. 4, Fig. 10): This species was found only at site 3. It recovered after three days, with the highest growth rate of $10.8 \%$ at $25^{\circ} \mathrm{C}$.

Thalassiosira sp. (Pl. 1, Fig. 5): This species appeared at site 3. It was recovered after three days, with the best growth rate of $9.8 \%$ at $25^{\circ} \mathrm{C}$.

Navicula erifuga (Pl. 3, Figs. 1 \& 2): It was observed at site 1 . Its recovery started after three days with a relative abundance of $9.5 \%$ at $15^{\circ} \mathrm{C}$.

Cyclotella sp. (Pl. 1, Fig. 4): This species was observed only at site 3. It recovered after three days and had the highest growth rate of $6.8 \%$ at $20^{\circ} \mathrm{C}$.

Surirella sp. 1 (Pl. 6, Fig. 7): This species appeared at site 3 only. Its regrowth started after three days, with a relative abundance of $6.8 \%$ at $30{ }^{\circ} \mathrm{C}$.

Amphora copulata (Pl. 5, Fig. 10): This species was found at site 2 only. It started to regrow after three days, with growth rate composing $6.25 \%$ of the total recovered diatom species $\mathrm{t}$ this site for $20^{\circ} \mathrm{C}$.

Caloneis permagna (Pl. 2, Fig. 8): This species was found at site 1 only. After three days of incubation, its growth rate accounted for $4.2 \%$ of the overall recovered diatom species at $25^{\circ} \mathrm{C}$.

The rest of the recovered taxa which included Cocconeis euglypta, Lindavia sp., Navicula viridula var. rostellata, Nitzschia brevissima, Nitzschia clausii, Tryblionella coarctata, Tryblionella plana, Halamphora sp. 2, Petrodictyon gemma, Surirella sp. 2, Nitzschia lorenziana, Gyrpsigma sp. did not exhibit any significant growth rate and their relative abundance was almost less than $1 \%$ of the total recovered assemblage (Table 2). 


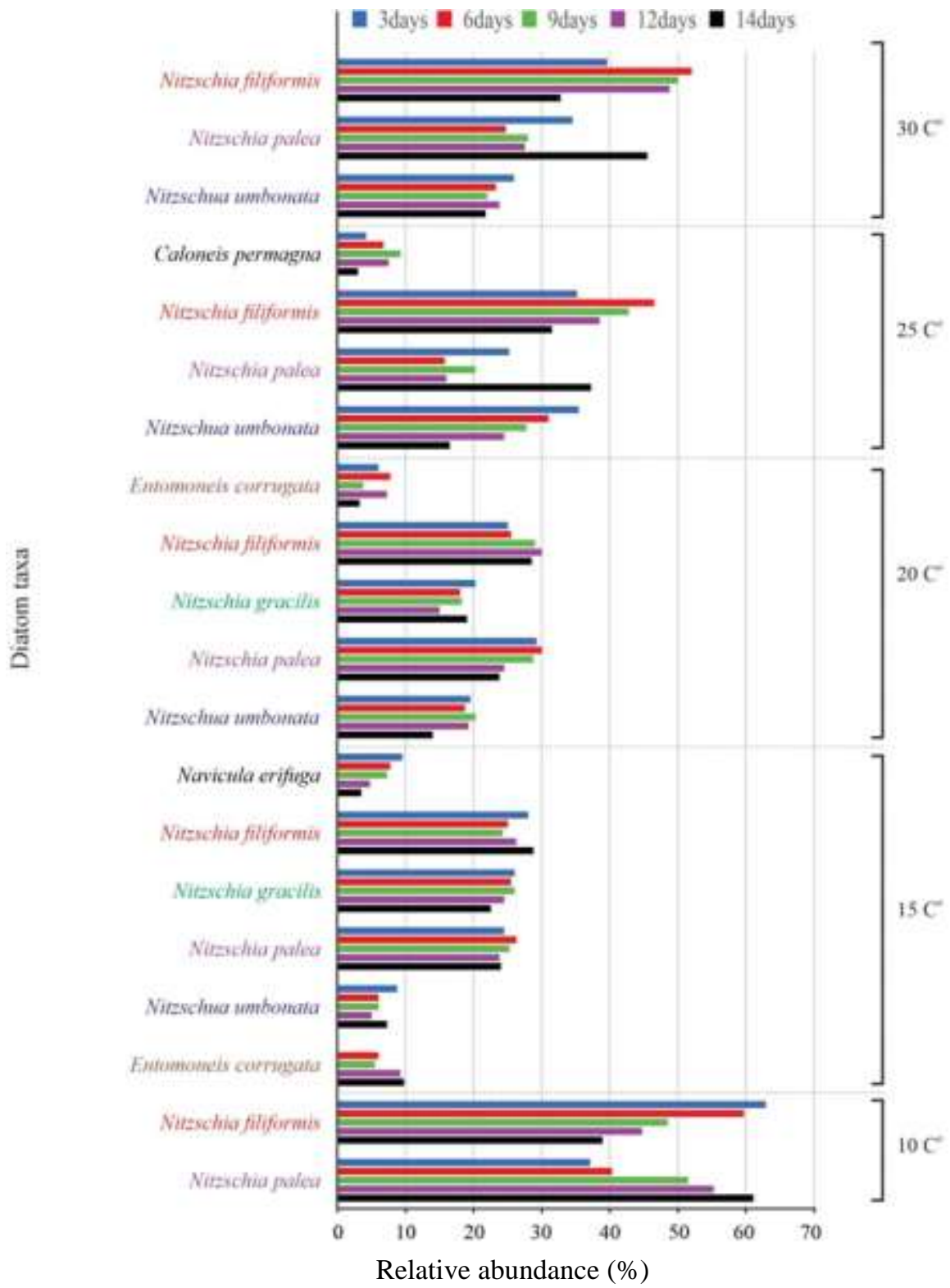

Figure 2: Relative abundance and recovery time of diatom species with different temperatures at site 1 . 


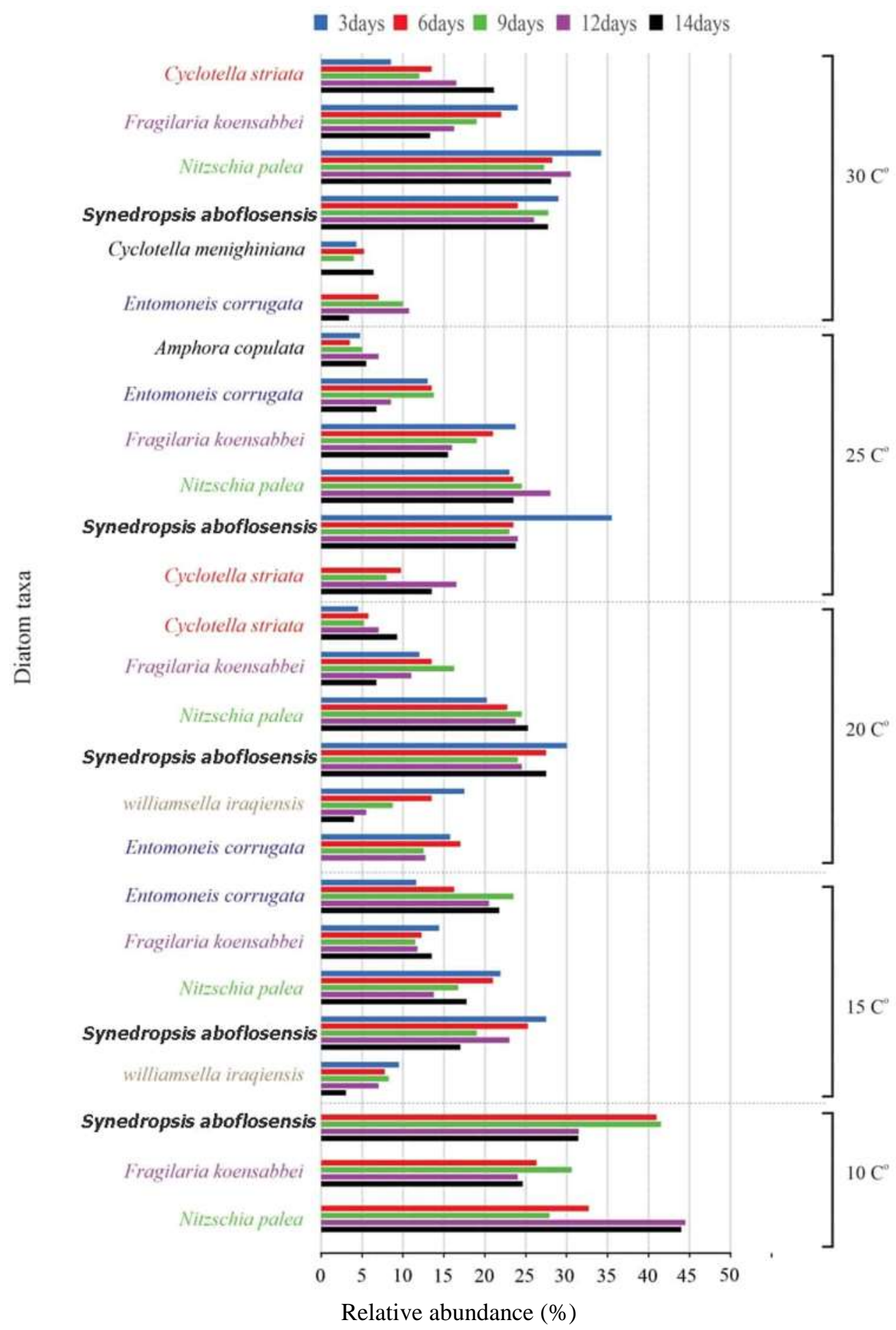

Figure 3: Relative abundance and recovery time of diatom species with different temperatures at site 2 . 


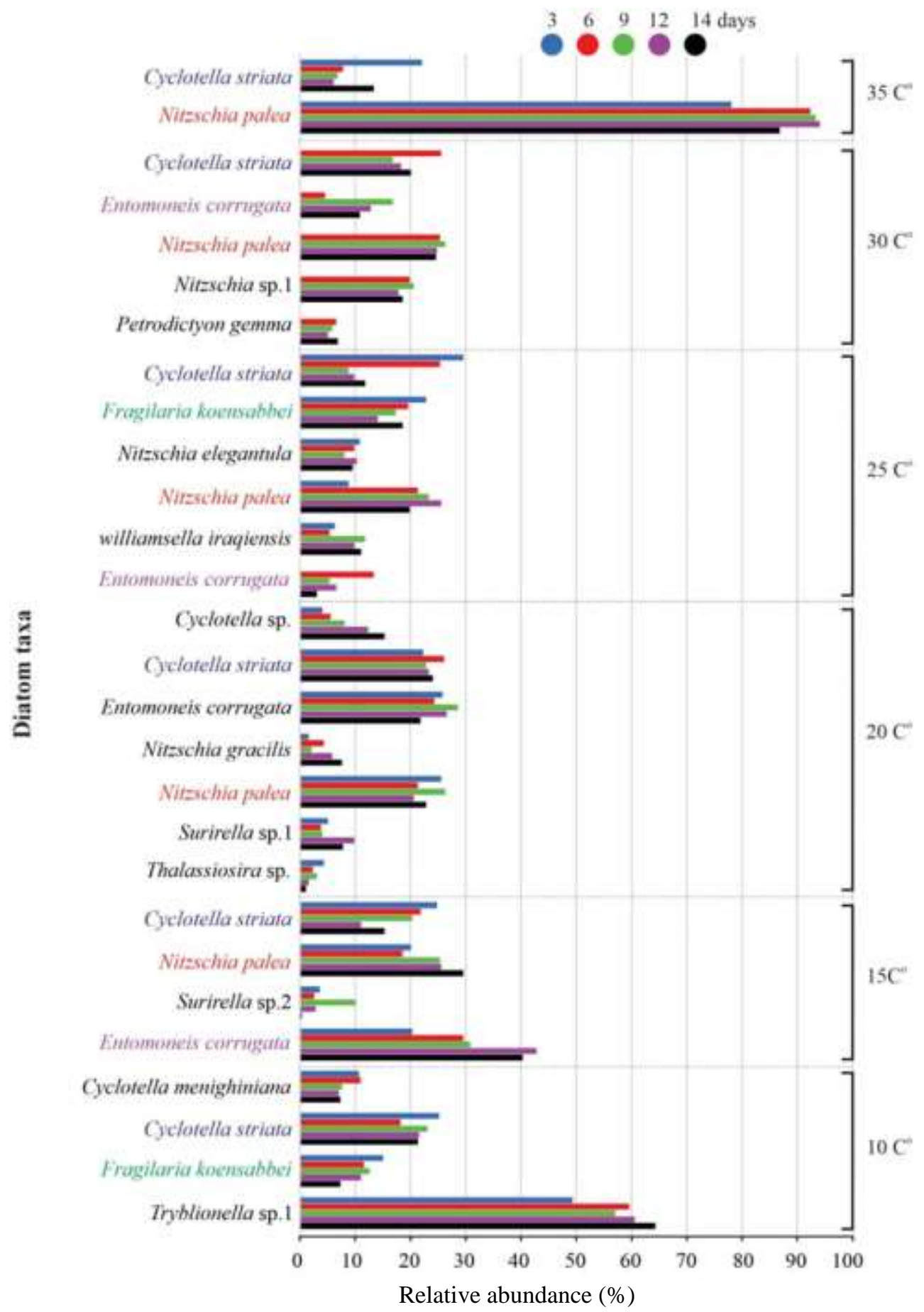

Figure 4: Relative abundance and recovery time of diatom species with different temperatures at site 3 . 


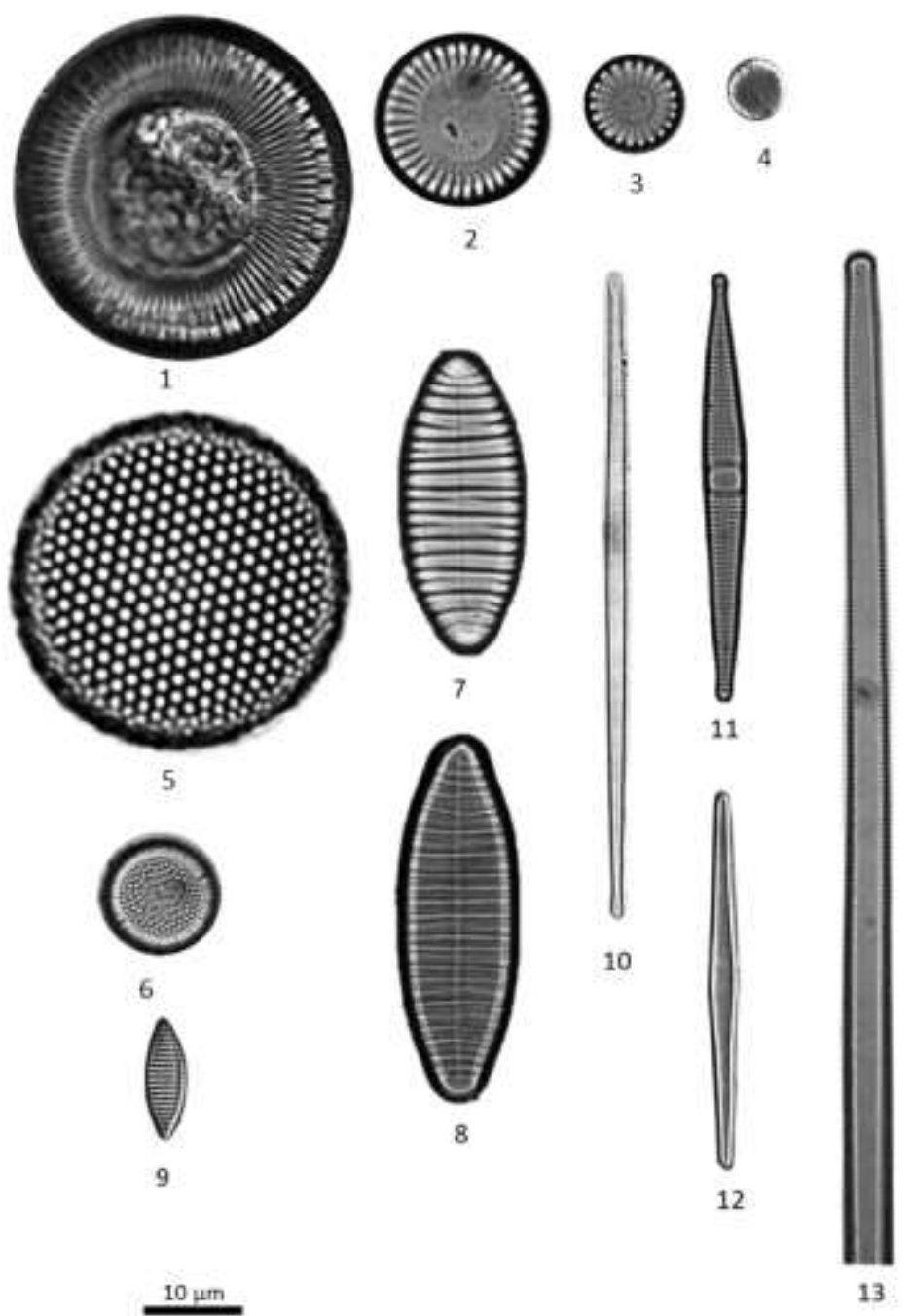

Plate 1: L. M. images of some benthic diatoms from Shatt Al-Arab river, Basrah, Iraq.

1. Cyclotella striata, 2, 3. Cyclotella menighiniana, 4. Cyclotella sp., 5. Thalassiosira sp., 6. Lindavia sp., 7, 8. Diatoma vulgaris, 9. Simonsenia sp., 10. Williamsella iraqiensis, 11. Ctenophora pulchella, 12. Synedropsis abuflosensis, 13. Fragilaria koensabbei. 


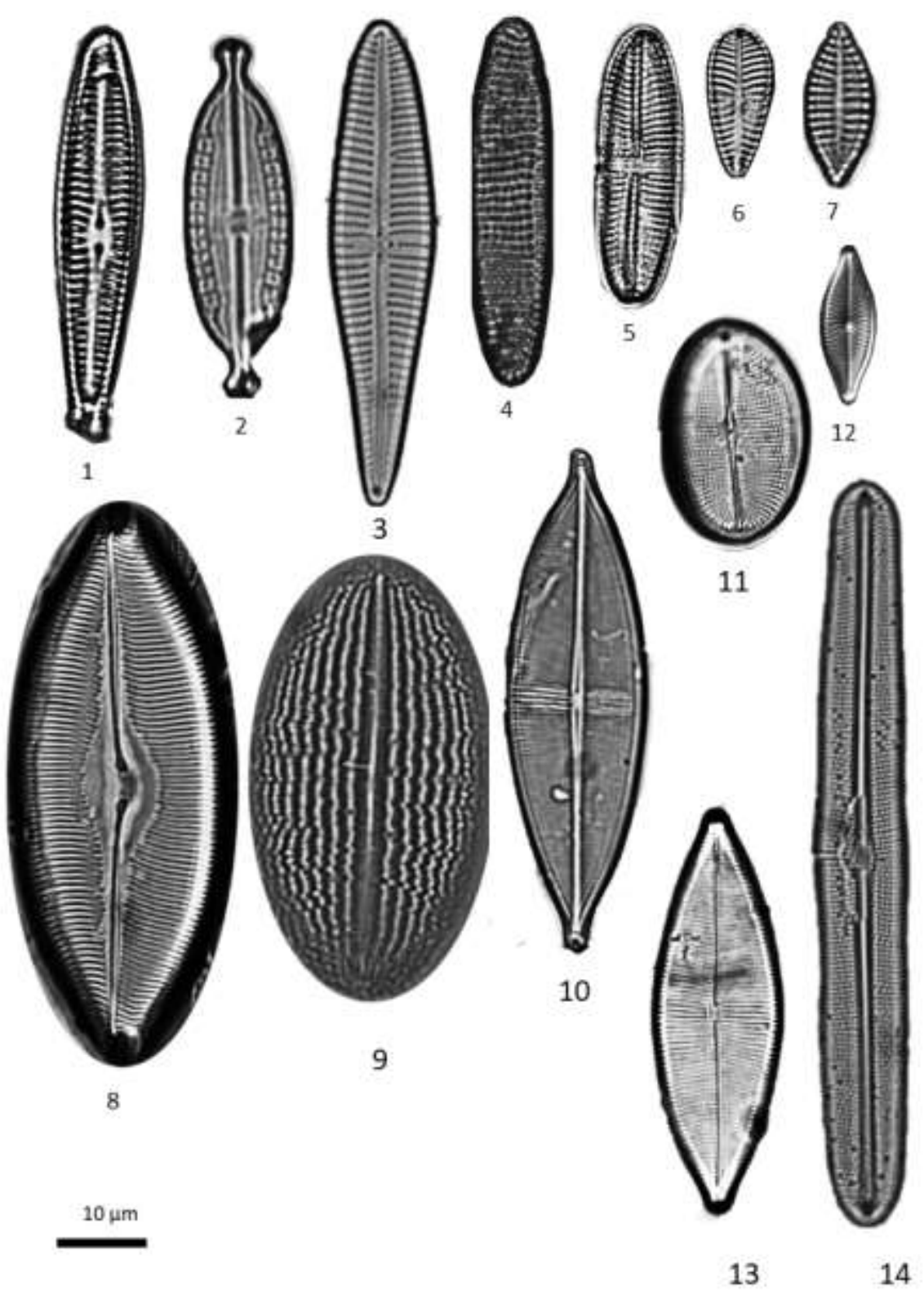

Plate 2: L. M. images of some benthic diatoms from Shatt Al-Arab river, Basrah, Iraq.

1. Rhoicosphenia abbriviata, 2. Mastogloia aff. Smithii, 3. Gomphonema affine, 4. Achnanthes brevipes var. intermedia (sternum valve), 5. Achnanthes brevipes var. intermedia (raphe valve), 6. Gomphonella olivacea, 7. Planothidium delicatulum, 8. Caloneis permagna, 9. Cocconeis euglypta, 10, 13. Prestauroneis crucicula, 11. Cocconeis pediculus, 12. Placoneis clementis, 14. Berkeleya scopulorum. 


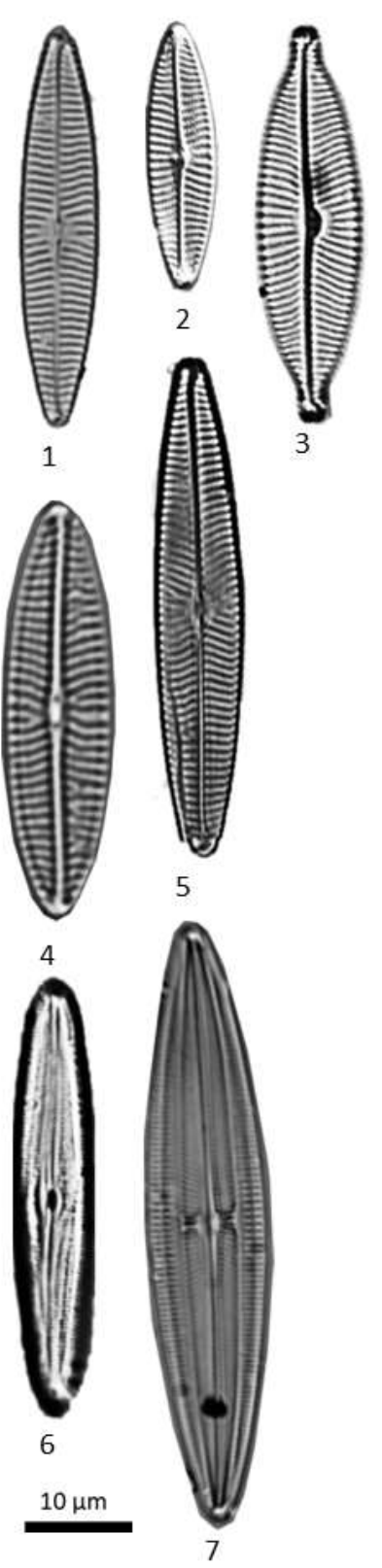

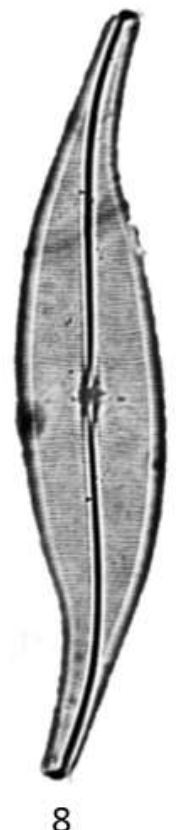

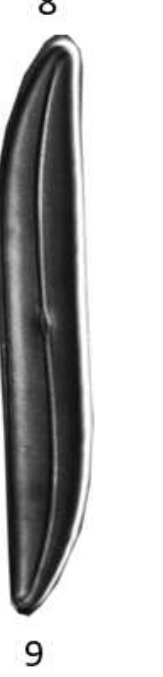

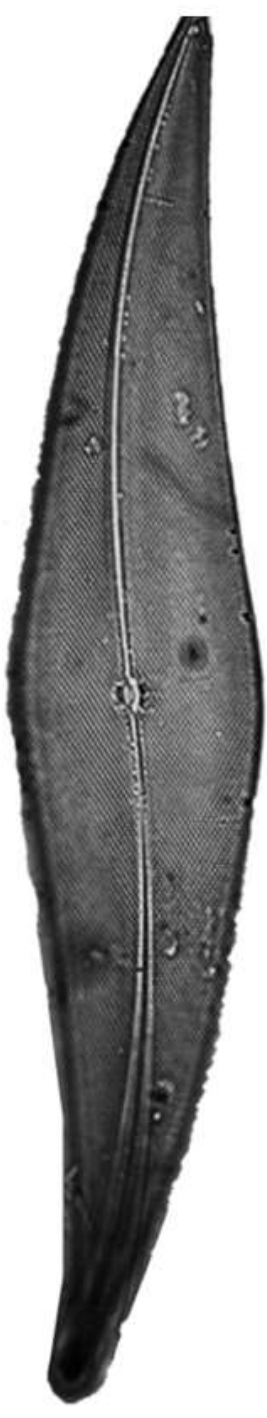

10

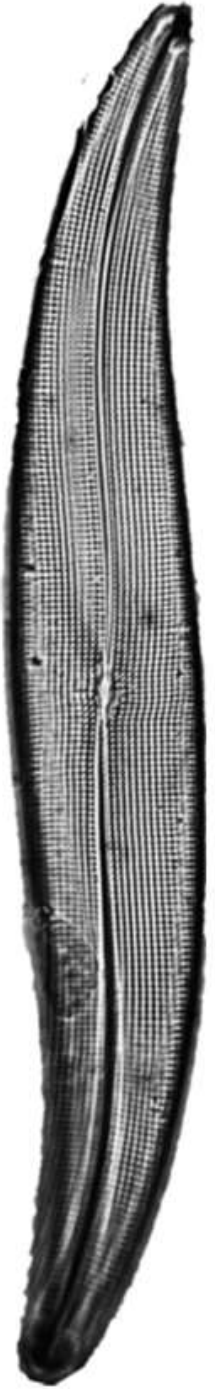

11

Plate 3: L. M. images of some benthic diatoms from Shatt Al-Arab river, Basrah, Iraq.

1, 2. Navicula erifuga, 3. Navicula viridula var. rostellata, 4. Navicula sp. 1, 5. Navicula sp. 2, 6. Scoliopleura basrensis, 7. Brachysira sp., 8. Gyrosigma wormleyi, 9. Gyrosigma sp., 10. Pleurosigma angulatum, 11. Gyrosigma acuminatum. 


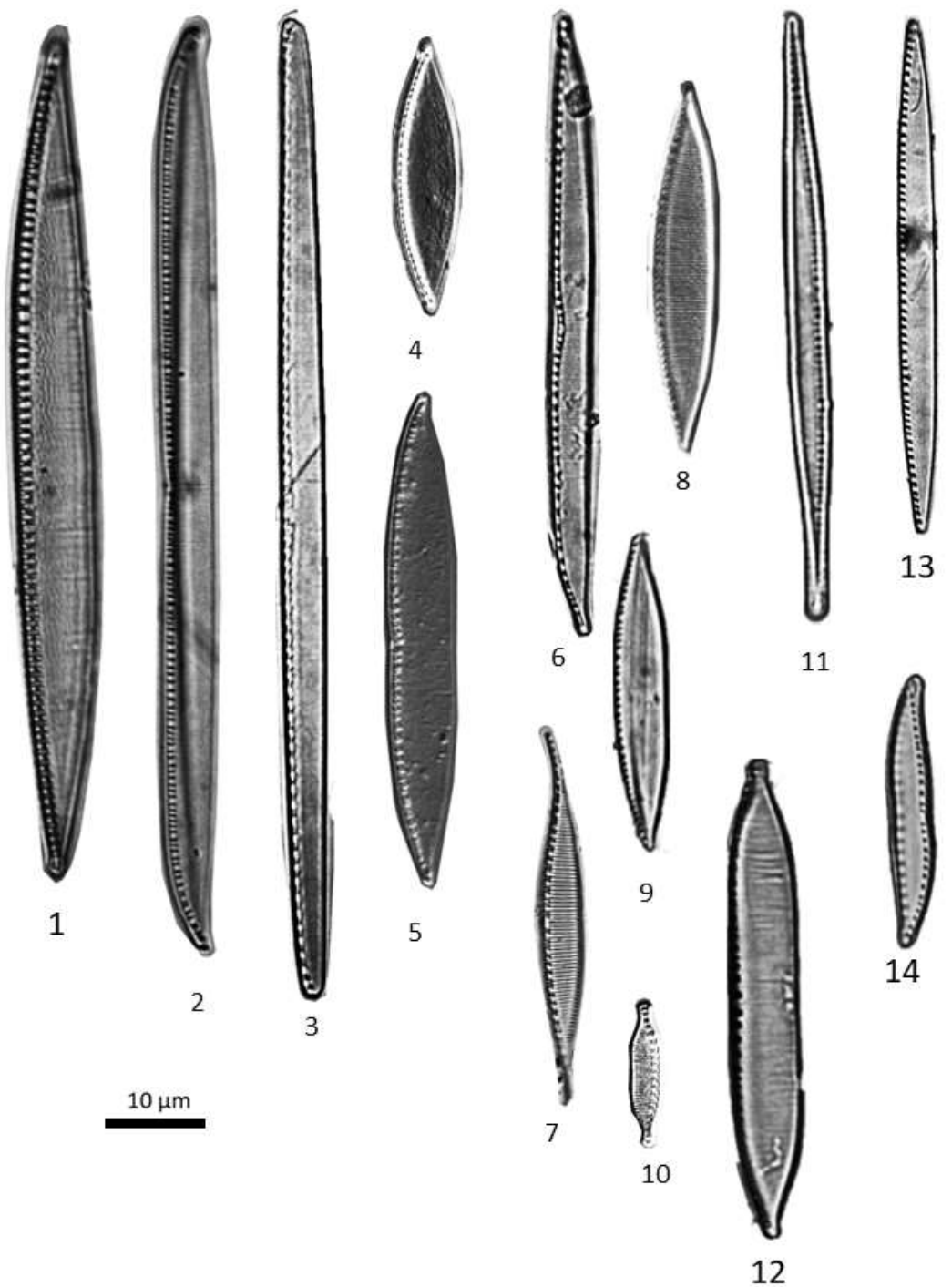

Plate 4: L. M. images of some benthic diatoms from Shatt Al-Arab river, Basrah, Iraq.

1. Nitzschia sigma, 2. Nitzschia hybrida, 3, 13. Nitzschia filiformis, 4. Nitzschia sp. 1, 5. Nitzschia sp. 2, 6. Nitzschia scalpelliformis, 7. Nitzschia lorenziana, 8, 9. Nitzschia palea, 10. Nitzschia elegantula, 11. Nitzschia gracilis, 12. Nitzschua umbonate, 14. Nitzschia brevissima. 


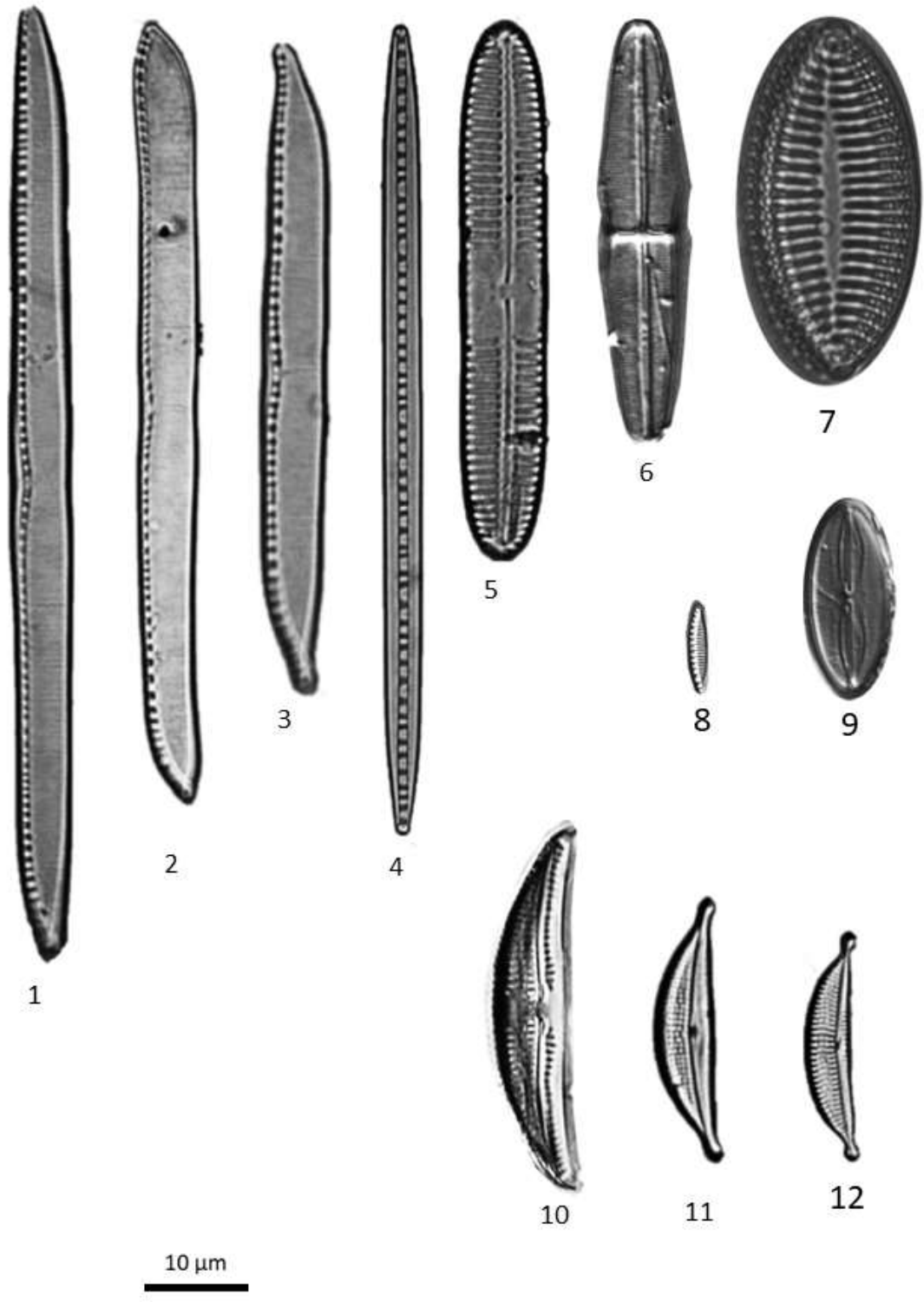

Plate 5: L. M. images of some benthic diatoms from Shatt Al-Arab river, Basrah, Iraq. 1, 2. Nitzschia obtusa, 3. Nitzschia clausii, 4. Bacillaria paxillifera, 5. Pinnularia quadratarea, 6. Craspedostauros britannicus, 7. Giffenia cocconeiformis, 8. Nitzschia invisitata, 9. Fallacia pygmaea, 10. Amphora copulata, 11. Halamphora sp. 1, 12. Halamphora sp. 2. 


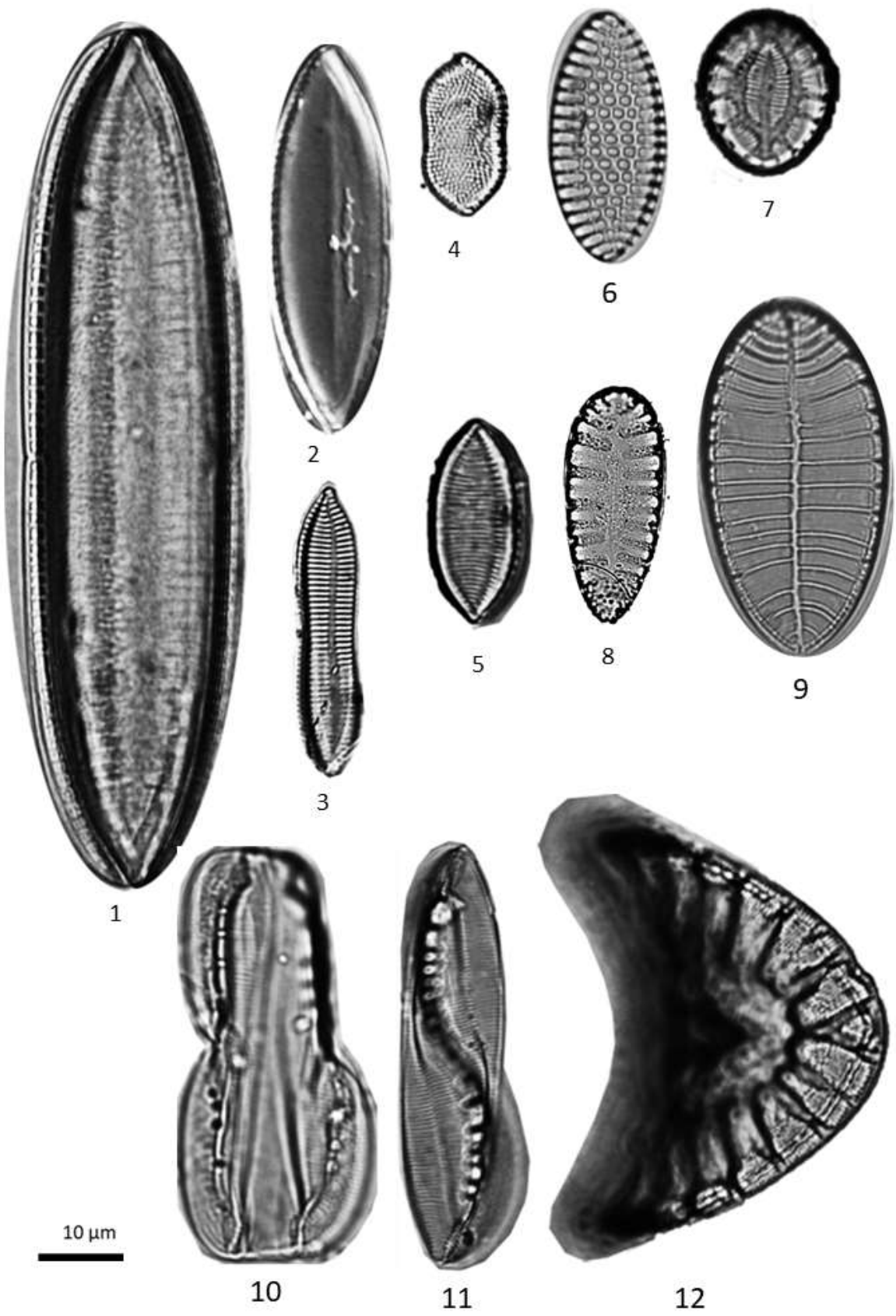

Plate 6: L. M. images of some benthic diatoms from Shatt Al-Arab river, Basrah, Iraq. 1. Tryblionella littoralis, 2. Tryblionella plana, 3. Tryblionella hungarica, 4. Tryblionella coarctata, 5. Tryblionella sp. 1, 6. Tryblionella granulata, 7. Surirella sp. 1, 8. Surirella striatula, 9. Petrodictyon gemma, 10, 11. Entomoneis corrugata, 12. Campylodiscus sp. 


\section{Discussion}

Despite of the limited sampling, both in time and number of samples, yet several of the encountered taxa were not previously reported in Shatt Al-Arab River and constitute new records to the diatom flora of Iraq (Al-Handal \& Abdulla, 1994; AlHandal \& Al-Shaheen, 2019). This could be attributed to the ongoing changes in the environmental conditions in the river which lead to either disappearance or appearance of new organisms (Al-Mayah \& Al-Asadi, 2018).

In the present investigation, an attempt to understand how diatoms respond to environmental stress, especially to high temperatures, was made. Therefore, epipelic diatoms collected from coastal line of Shatt Al-Arab river, were exposed to desiccation at $50{ }^{\circ} \mathrm{C}$ in order to monitor their ability to recover such harsh conditions. Diatoms tolerance to desiccation is not well known although few studies pointed to limited number of species with certain level of regrowth after exposing to prolonged period of exposure to air (Hargraves \& French, 1975; Schmid, 2009; Souffreau et al., 2010).

One of the most common recovered species was Nitzschia palea which appeared at all sites and constituted $78 \%$ of the total recovered diatoms at site 3 . It is not unlikely that this species reappeared in such high frequency, it is well known to occur in different environmental conditions (Ahirwar et al., 2020) and is common in lotic and lentic habitats and sometimes the most abundant taxon (Trobajo et al., 2009). It is also tolerant to high levels of toxic metal pollutants and pesticides (Wang et al., 2020). This capability of surviving in extreme conditions, such as desiccation, is attributed to its capability of tolerating wide environmental fluctuations. $N$. palea had a maximum growth rate at all temperatures $\left(10-35^{\circ} \mathrm{C}\right)$. Previously, it was thought that this species is unable to grow at temperatures above $30{ }^{\circ} \mathrm{C}$ (Beliveau \& Hickman, 1982), whereas in this study it grew at $35{ }^{\circ} \mathrm{C}$, providing evidence that it can tolerate a higher temperature range.

Nitzschia filiformis is another species that recovered with a high growth rate, and accounted for $62.2 \%$ of the total diatom species recovered at site $1 . N$. filiformis has a wide ecological preference and was found to flourish in areas polluted by industrial effluents (Lange-Bertalot et al., 2017). This species is one of the most abundant tube-forming diatoms (Carr \& Hergenrader, 1987; Fricke et al., 2017). This might explain its ability to withstand desiccation. The present results indicated that its optimum growth was at $10{ }^{\circ} \mathrm{C}$ and $30{ }^{\circ} \mathrm{C}$, with less appearance at the other treatments.

Tryblionella sp. 1 was one of the most recovered diatoms and constituted $49.28 \%$ at $10{ }^{\circ} \mathrm{C}$ at site 3 . It was only recovered at this temperature, indicating its narrow temperature preference. Since the definite identity of this species is not known, it was not possible to relate its desiccation tolerance to any ecological preference.

The newly found species, Synedropsis abuflosensis occurred at site 2 only. It was recovered with a high growth rate of $41 \%$ at $10{ }^{\circ} \mathrm{C}$ and $35.5 \%$ at $25{ }^{\circ} \mathrm{C}$. Synedropsis is a small genus with only few representatives. It was not previously recorded from all Asian inland or marine habitats. Ecology of this new taxon is 
different from all other known Synedropsis species by occurring as benthic and epiphytic on algal mats which add a new environmental preference to this genus whose taxa are either sea-ice forms (Hasle et al., 1994) or planktonic (Melo et al., 2003; Prasad \& Livingston, 2005).

Nitzschua umbonata recovered at sites 1 with a growth rate of $35.4 \%$ at $25{ }^{\circ} \mathrm{C}$ and $25.9 \%$ at $30{ }^{\circ} \mathrm{C}$. This species occurs sporadically in eu- to polytrophic, saprobically impacted freshwater habitats which are rather similar to Shatt Al-Arab River conditions. It is used as organic pollution indicator (Ndiritu et al., 2006; Simsek, 2018). Such environmental stress resistance may explain its regrowth after desiccation in the present study.

Fragilaria koensabbei is another species which recovered at sites 2 and 3 with a growth rate of $26.3 \%$ at $10{ }^{\circ} \mathrm{C}$ and $24 \%$ at $30{ }^{\circ} \mathrm{C}$. The distribution and ecology of this species is not well known as it was recently described from Shatt Al-Arab river. It is common, however, in Southern Iraq as planktonic and epiphytic (AlHandal \& Al-Shaheen, 2019). The present results indicated that F. koensabbei regrowth was achieved at all temperature treatments except for $35^{\circ} \mathrm{C}$.

Nitzschia gracilis was recovered at sites 1 and 2 with largest growth rate of $26 \%$ and $20.3 \%$ at 15 and $20{ }^{\circ} \mathrm{C}$, respectively. It was previously documented that favourable temperature of optimum growth of this species is in the range of 15-30 ${ }^{\circ} \mathrm{C}$ (Beliveau \& Hickman, 1982) which coincides with the present finding. $N$. gracilis is a widely distributed species (Hartley et al., 1986; Krammer \& LangeBertalot, 1988), but its environmental preference is rarely known. Its recovery in the present study, however, indicates its resistance to temperature extremes.

Entomoneis corrugata recovered at all sites with an ability to regrow at all temperature treatments except for $35^{\circ} \mathrm{C}$. It reached maximum relative abundance of $25.8 \%$ at $20{ }^{\circ} \mathrm{C}$ (site 3 ) and $15.8 \%$ at $20{ }^{\circ} \mathrm{C}$ (site 2). E. corrugata is common in Southern Iraq (Al-Handal \& Al-Shaheen, 2019) but with limited distribution in the World (Witkowski et al., 2000). However, its common occurrence in Shatt Al-Arab River exhibits its tolerance to wide environmental fluctuations.

The two species of Cyclotella; $C$. striata and C. menighiniana showed noticeable recovery although their environmental preference vary considerably. $C$. striata is a marine to brackish water form and considered as good indicator to environmental changes (Abate et al., 2017). It was recovered at site 3 with a relatively high growth rate $(25.1 \%)$ at $10{ }^{\circ} \mathrm{C}$ and showed the ability to grow at $35{ }^{\circ} \mathrm{C}$, constituting $22 \%$ of all other taxa. C. menighiniana is an organic and industrial pollution tolerant and inhabit variable habitats (Buric et al., 2007). It was recovered at sites 2 and 3, with the highest growth rate of $10.63 \%$ at $10{ }^{\circ} \mathrm{C}$ at site 3 .

A number of species including Cyclotella sp., Surirella sp. 1 and Thalassiosira sp. were able recover at site 3 only with relatively high relative abundance (Fig. 4). All these taxa are of marine origin which explains their occurrence at site 3 which is exposed to sea water during high tide. Their recovery indicates their ability to tolerate temperature extremes.

Other species which their recovery was confined to one site included Navicula erifuga and Caloneis permagna (site 1) and both Amphora copulata and 
Williamsella iraqiensis (site 2). Their relative abundance was relatively small in comparison to the other taxa, but they exhibited noticeable tolerance to high temperature.

It was previously documented that some species of diatoms can survive desiccation by producing resting spores and resting cells, which is a successful way for surviving environmental stress (Hargraves \& French, 1975; Souffreau, 2011). Resting cells act as a seed bank in the sediment (Jewson et al., 2006; Poulicková et al., 2008) which could explain the rapid spring blooms of diatoms. Resting cells and spores are also resistant to dark, cold and nutrient limited conditions (McQuoid \& Hobson, 1995). According to Sanyal et al. (2019), resting spores of diatoms can survive for centuries in nature and the diatoms spores are still viable if the perfect conditions are given. The present results showed that the germination period for most of the species exposed to desiccation can occur within a short period, mostly after 72 hours after return of natural conditions, which coincide with Sanyal et al. (2019).

\section{Acknowledgments}

The authors wish to thank Dr Dunya A.H. Al-Abbawy of the Ecology Department, University of Basrah for providing laboratory equipment. Our thanks are also due to Mr. Aqeel A. Al-Waeli of the Marine Science Centre, University of Basrah for his help in microscopy.

\section{References}

Abate, R.; Gao, Y.; Chen, C.; Liang, J.; Chen, W.; Sun, L. \& Kifile, D. (2017). Environmental change and its effects on inter-decadal variations of diatom production, species composition and frustule dissolution in a coastal marginal sea. Chin. J. Oceanol. Limnol., 35(6): 1362-1373. DOI:10.1007/s00343-0170084-5.

Abdullah, S.S. (1990). An investigation to the river load of Shatt Al-Arab in Basrah. M. Sc. Thesis, Mar. Sci. Cent., Univ. of Basrah: 98 pp. (In Arabic).

Ahirwar, A.; Gupta, S.; Kashyap, M.; Shukla, P. \& Vinayak, V. (2020). Differential cell viability in Nitzschia palea on exposure to different organic and inorganic environmental effluents. Int. J. Environ. Sci. Technol., 17(1): 493-504.

Al-Handal, A.Y. \& Al-Shaheen, M.A. (2019). Diatoms in the wetlands of Southern Iraq. Bibl. Diatomol., 67: 1-252.

Al-Handal, A.Y. \& Wulff, A. (2008). Marine benthic diatoms from Potter Cove, King George Island, Antarctica. Bot. Mar., 51(1): 51-68. DOI:10.1515/ BOT.2008.007.

Al-Handal, A.Y. \& Abdullah, D.S. (1994). On the diatoms ecology of Basrah District, Southern Iraq. Mar. Mesopot., 9(2): 329-342.

Al-Hassani, J.; Al-Saadi, H. \& Qassem, T. (2009). Effect of some environmental conditions of diatom growth rate. Al-Mustansiriya J. Sci., 20(3): 24-31. (In Arabic). 
Al-Hassan, L.A.J. \& Hussain, N.A. (1985). Hydrological parameters influencing the penetration of Arabian Gulf fishes into the Shatt Al-Arab river. Iraq. Cybium, 9(1): 7-16.

Al-Mayah, A.A. \& Al-Asadi, W.M. (2018). The impact of increase salinity on the aquatic plants assemblage in Shatt Al-Arab river, Iraq. Marsh Bull., 13(2): $12-24$.

Al-Shawi, I.J.; Abdullah, A.M. \& Hussein, S.A. (2012). Impact of Al-Najebiya thermal energy power plant on aquatic ecosystem of Garmat Ali Canal. II: Monthly differences in abundance and distribution of algae. Basrah J. Sci., 30(1): 34-44.

Anderson, N.J. (2000). Diatoms, temperature and climatic change: Mini view. Eur. J. Phycol., 35(4): 307-314.

Behrenfeld, M.J.; O’Malley, R.T.; Siegel, D.A.; McClain, C.R.; Sarmiento, J.L.; Feldman, G.C.; Milligan. A.J.; Falkowski, P.G.; Letelier, R.M. \& Boss, E. (2006). Climate-driven trends in contemporary ocean productivity. Nature, 444: 752-755. DOI:10.1038/nature05317.

Beliveau, D.J. \& Hickman, M. (1982). Isolation and response to temperature of five diatom species. Arch. Protistenk., 126(3): 355-370.

Berger, W.H. (2007). Cenozoic cooling, Antarctic nutrient pump, and the evolution of whales. Deep Sea Res., Part II, 54(21-22): 2399-2421. DOI:10.1016/ j.dsr2.2007.07.024.

Berges, J.A.; Varela, D.E. \& Harrison, P.J. (2002). Effects of temperature on growth rate, cell composition and nitrogen metabolism in the marine diatom Thalassiosira pseudonana (Bacillariophyceae). Mar. Ecol. Prog. Ser., 225: 139-146. DOI:10.3354/meps225139.

Bopp, L.; Aumont, O.; Cadule, P.; Alvain, S. \& Gehlen, M. (2005). Response of diatoms distribution to global warming and potential implications: A global model study. Geophys. Res. Lett., 32(19): 1- 4. DOI:10.1029/2005GL023653.

Burić, Z.; Kiss, K.T.; Ács, E.; Viličić, D.; Caput Mihalić, K. \& Carić, M. (2007). The occurrence and ecology of the centric diatom Cyclotella choctawhatcheeana Prasad in a Croatian estuary. Nova Hedwigia, 84(1-2): 135-154. DOI:10.1127/0029-5035/2007/0084-0135.

Carr, J.M. \& Hergenrader, G.L. (1987). Occurrence of three Nitzschia (Bacillariophyceae) taxa within colonies of tube-forming diatoms. J. Phycol., 23(1): 62-70. DOI:10.1111/j.0022-3646.1987.00062.x.

Dickman, M.D.; Peart, M.R. \& Yim, W.W.-S. (2005). Benthic diatoms as indicators of stream sediment concentration in Hong Kong. Int. Rev. Hydrobiol., 90(4): 412-421. DOI:10.1002/iroh.200410806.

Eaton, J.W. \& Moss, B. (1966). The estimation of numbers and pigment content in epipelic algal populations. Limnol. Oceanogr., 11(4): 584-595. DOI:10.4319/ lo.1966.11.4.0584.

Fricke, A.L.; Kihara, T.C.; Kopprio, G.A. \& Hoppenrath, M. (2017). Anthropogenically driven habitat formation by a tube dwelling diatom on the Northern Patagonian Atlantic coast. Ecolog. Indic., 77(3): 8-13. 
Gale, D.S. (2016). Diatoms as indicators of ecological change in freshwater reservoirs of South East Queensland. Ph. D. Thesis, Univ. Queensland: 120 pp. DOI:10.14264/uql.2016.64.

GBIF (2021). Global Biodiversity Information Facility, on-line database, http://www.gbif.org. (Accessed 4 June 2021).

Hargraves, P.E. \& French F.W. (1975). Observations on the survival of diatom resting spores. Nova Hedwigia, 53: 229-238.

Hartley, B.; Ross, R. \& Williams, D.M. (1986). A check-list of the freshwater, brackish and marine diatoms of the British Isles and adjoining coastal waters. J. Mar. Biol. Ass. U.K., 66(3): 531-610.

Hasle, G.R.; Medlin, L.K. \& Syvertsen, E.E. (1994): Synedropsis gen. nov., a genus of araphid diatoms associated with sea ice. Phycologia, 33(4): 248-270. DOI:10.2216/i0031-8884-33-4-248.1.

Hussein, S.A.; Al-Shawi, I.J. \& Abdullah, A.M. (2009). Effect of heated effluents discharged from Al-Hartha electricity power station on the ecosystem of the Shatt Al-Arab river: II. Seasonal variations in abundance and distribution of algae. J. Basrah Res. (Sci.), 35(1): 34-42.

Jewson, D.H.; Lowry, S.F. \& Bowen, R. (2006). Co-existence and survival of diatoms on sand grains. Eur. J. Phycol., 41(2): 131-146. DOI:10.1080/ 09670260600652903.

Krammer, K. \& Lange-Bertalot, H. (1988). Bacillariophyceae, Teil 2: Bacillariaceae, Epithemiaceae, Surirellaceae. In: Ettl, H.; Gerloff, J.; Heynig, H. \& Mollenhauer, D. (eds.). Süsswasserflora von Mitteleuropa, Band 2/2. Gustav Fischer Verlag, Stuttgart: 596 pp.

Lange-Bertalot, H.; Hofmann, G.; Werum, M. \& Cantonati, M. (2017). Freshwater benthic diatoms of Central Europe: Over 800 common species used in ecological assessment. English edition with updated taxonomy and added species. Koeltz Bot. Books, Schmitten-Oberreifenberg: 942 pp.

Lewandowska, A.M.; Boyce, D.G.; Hofmann, M.; Matthiessen, B.; Sommer, U. \& Worm, B. (2014). Effects of sea surface warming on marine plankton. Ecol. Lett., 17(5): 614-623. DOI:10.1111/ele.12265.

Maguire, A.; Yamakawa, Y.; Mixson, S.; Lowe, R. \& Kociolek, P. (2013). Diatom diversity and community structure along a thermal gradient in the Maple River of Northern Michigan. Univ. Michig. Undergr. Res. Forum: 4 pp. http:// hdl.handle.net/2027.42/96973.

Mann, D.G.; Crawford, R.M \& Round, F.E. (2017). Bacillariophyta. Handbook of the Protists. Springer, Cham: 1657 pp.

McQuoid, M.R. \& Hobson, L.A. (1995). Importance of resting stages in diatom seasonal succession. J. Phycol., 31(1): 44-50. DOI:10.1111/j.0022-3646. 1995. 00044.x.

Melo, S.; Torgan, L.C.; Menezes, M.; Huszar, V.L.M.; Correa, J.D., Jr. \& Bozelli, R.L. (2003). Taxonomy and ecology of Synedropsis roundii sp. nov. (Bacillariophyta) from a tropical brackish coastal lagoon, south-eastern Brazil. Phycologia, 42: 71-79. DOI:10.2216/10031-8884-42-1-71.1. 
Mohamed, A.R.M. \& Abood, A.N. (2017). Ecological health assessment of the Shatt Al-Arab river, Iraq. IOSR J. Agric. Vet. Sci., 10(10): 1-8. DOI:10.9790/2380-1010010108.

Naff, T. \& Hanna, G. (2003). The marshes of Southern Iraq: A hydro-engineering and political profile. In: Nicholson, E. \& Clark, P. (eds.). The Iraqi marshlands: A human and environmental study. Politicos Publ., London: 169200.

Ndiritu, G.G.; Gichuki, N.N. \& Triest, L. (2006). Distribution of epilithic diatoms in response to environmental conditions in an urban tropical stream, Central Kenya. Biodivers. Conserv., 15(10): 3267-3293. DOI:10.1007/s10531-0050600-3.

Pinckney, J.; Papa, R. \& Zingmark, R. (1994). Comparison of high-performance liquid chromatographic, spectrophotometric, and fluorometric methods for determining chlorophyll a concentration in estuarine sediments. J. Microbiol. Methods, 19(1): 59-66. DOI:10.1016/0167-7012(94)90026-4.

Poulicková, A.; Lysáková, M.; Hašler, P. \& Lelková, E. (2008). Fishpond sediments - the source of palaeoecological information and algal "seed banks". Nova Hedwigia, 86(1-2): 141-153. DOI:10.1127/0029-5035/2008/ 0086-0141.

Prasad, A.K.S.K. \& Livingston, R.J. (2005). Fine structure and taxonomy of Synedropsis karsteteri sp. nov. (Fragilariaceae, Bacillariophyta), a bloomforming, brackish-water, planktonic, araphid diatom from Perdido Bay, northeastern Gulf of Mexico. Diatom Res., 20(1): 145-162. DOI:10.1080/ 0269249X.2005.9705624.

Prelle, L.R.; Graiff, A.; Gründling-Pfaff, S.; Sommer, V.; Kuriyama, K. \& Karsten, U. (2019). Photosynthesis and respiration of Baltic Sea benthic diatoms to changing environmental conditions and growth responses of selected species as affected by an adjacent peatland (Hütelmoor). Front. Microbiol., 10, 1500: 119. DOI:10.3389/fmicb.2019.01500.

Quiroga, I. \& Chrétiennot-Dinet, M.J. (2004). A new species of Minidiscus (Diatomophyceae, Thalassiosiraceae) from the eastern English Channel, France. Bot. Mar., 47: 341-348. DOI:10.1515/BOT.2004.040.

Renaudie, J. (2016). Quantifying the Cenozoic marine diatom deposition history: Links to the C and Si cycles. Biogeosciences, 13: 6003-6014. DOI:10.5194/ bg-13-6003-2016.

Round, F.E.; Crawford, R.M. \& Mann, D.G. (1990). The diatoms: Biology and morphology of the genera. Cambridge Univ. Press: 747 pp.

Sanyal, A.; Larsson, J.; van Wirdum, F.; Andrén, T.; Moros, M.; Lönn, M. \& Andrén, E. (2019). Not dead yet: Diatom resting spores can survive in nature for several millennia. BioRxiv. DOI:10.1101/285122.

Schmid, A.-M.M. (2009). Induction of resting-spores in the pennate diatom Navicula (Craticula) cuspidata by uncoupling of the cell and the plastid cycles. Nova Hedwigia, 135: 85-101. 
Schneider, S.C.; Lawniczak, A.E.; Picińska-Faltynowicz, J. \& Szoszkiewicz, K. (2012). Do macrophytes, diatoms and non-diatom benthic algae give redundant information? Results from a case study in Poland. Limnologica, 42(3): 204-211. DOI:10.1016/j.limno.2011.12.001.

Simsek, K. (2018). Mixed wastewater use for culture of diatom Nitzschia umbonata (Ehrenberg Lange-Bertalot, 1978). Int. J. Res. Innov. Earth Sci., 5(6): 131135.

Souffreau, C. (2011). Biogeography, species diversity and stress tolerance of aquatic and terrestrial diatoms. Ph. D. Thesis, Ghent Univ: 285 pp.

Souffreau, C.; Vanormelingen, P.; Verleyen, E.; Sabbe, K. \& Vyverman, W. (2010). Tolerance of benthic diatoms from temperate aquatic and terrestrial habitats to experimental desiccation and temperature stress. Phycologia, 49(4): 309-324. DOI:10.2216/09-30.1.

Taylor, R.L.; Caldwell, G.S.; Dunstan, H.J. \& Bentley, M.G. (2007). Short-term impacts of polyunsaturated aldehyde-producing diatoms on the harpacticoid copepod, Tisbe holothuriae. J. Exp. Mar. Biol. Ecol., 341(1): 60-69. DOI:10.1016/j.jembe.2006.10.028.

Trobajo, R.; Clavero, E.; Chepurnov, V.A.; Sabbe, K.; Mann, D.G.; Ishihara, S. \& Cox, E.J. (2009). Morphological, genetic and mating diversity within the widespread bioindicator Nitzschia palea (Bacillariophyceae). Phycologia, 48(6): 43-459. DOI:10.2216/08-69.1.

Wang, Y.; Mu, W.; Sun, X.; Lu, X.; Fan, Y. \& Liu, Y. (2020). Physiological response and removal ability of freshwater diatom Nitzschia palea to two organophosphorus pesticides. Chem. Ecol., 36(9): 881-902. DOI:10.1080/ 02757540.2020 .1784883$.

Warkiewicz, E.; Strączek, A.; Latowski, D. \& Bojko, M. (2018). Acclimatization of diatom Phaeodactylum tricornutum to long-term environmental temperature and light intensity changes. Proc. $4^{\text {th }}$ World Cong. New Technol., Madrid: August 19-21, 2018, Paper No. ICEPR 146: 6 pp. DOI:10.11159/icepr18.146.

Witkowski, A.; Lange-Bertalot, H. \& Metzeltin, D. (2000). Diatom flora of marine coasts I. Iconogr. Diatomol., 7: 1-925.

Zhang, Y.; Peng, C.; Wang, Z.; Zhang, J.; Li, L.; Huang, S. \& Li, D. (2018). The species-specific responses of freshwater diatoms to elevated temperatures are affected by interspecific interactions. Microorganisms, 6(3), 82: 1-16. DOI: 10.3390/microorganisms6030082. 